\title{
XÂY DựNG PHƯƠNG PHÁP ĐỊNH LỰ̛̂NG NHANH VI KHUẨN LACTOBACILIUS ACIDOPHILUS TRONG MEN VI SINH BẰNG KỸ THUẠT REAL-TIME PCR
}

\author{
Phạm Thị Lệ Quyên, Phạm Nhu Trọng, Nguyễn Thùy Linh, Nguyễn Thành Trung \\ Viện Kiểm nghiệm an toàn vệ sinh thực phẩm quốc gia
}

(Ngày đến tòa soạn: 25/12/2018; Ngày sủa bài sau phản biện: 25/1/2019; Ngày chấp nhận đăng: 5/2/2019)

\section{Tóm tắt}

T actobacillus có tác dụng sinh học, hỗ trợ tiêu hóa được sử dụng rộng rãi trong các sản phẩm sữa _như sữa chua, phụ gia thực phẩm, dược phẩm. Trong đó, Lactobacillus acidophilus (L. acidophilus) thường được dùng trong các sản phẩm sữa lên men như yogurt và thực phẩm chức năng. Tuy nhiên, ở Việt Nam hiện nay chưa có phương pháp tiêu chuẩn để định lượng L. acidophilus. Để đáp ứng yêu cầu thực tế, chúng tôi xây dựng phương pháp định lượng L. acidophilus bằng real-time PCR dựa trên trình tự đoạn gen Hsp. Giới hạn định lượng của phương pháp là $10^{5} \mathrm{CFU} / \mathrm{g} / \mathrm{mL}$, phù hợp cho đánh giá chất lượng sản phẩm men vi sinh với công bố chất lượng lớn hơn $10^{6} \mathrm{CFU} / \mathrm{g} / \mathrm{mL}$. Độ đặc hiệu của phương pháp là $100 \%$ khi so sánh với các chủng không đặc hiệu và độ lặp lại $\mathrm{S}_{\mathrm{r}}<0,125$, phù hợp với yêu cầu của ISO 16140:2005 và AOAC:2016 phụ lục $\mathrm{F}$ đối với thẩm định phương pháp vi sinh.

Tù khóa: Lactobacillus acidophilus, real-time PCR, men vi sinh.

\section{1. ĐÃT VẤN ĐỀ}

Theo tổ chức y tế thế giới WHO: "Probiotics là các vi sinh vật sống khi được đưa một lượng cần thiết vào cơ thể sẽ đem lại hiệu quả có lợi cho cơ thể". Probiotic được tìm thấy trong thực phẩm và cả các chất bổ sung gồm sữa chua, đồ uống từ sữa chua, sữa lên men và chưa lên men, đậu tương lên men và một số nước hoa quả, đồ uống đậu nành.

L. acidophilus là một loại Probiotics phổ biến sinh sống trong hệ tiêu hóa, hệ bài tiết và bộ phận sinh dục của người nhưng không gây ra bệnh. L. acidophilus thường được dùng trong các sản phẩm sữa lên men như yogurt và các thực phẩm chức năng. L. acidophilus được sử dụng để chữa trị và phòng chống các bệnh tiêu chảy, cũng như các bệnh nhiễm trùng và bệnh ngoài da. Mặc dù được sử dụng như là phương tiện sinh học, nhưng quá trình phân tích những sản phẩm có chứa L. acidophilus lại cho thấy sự không đảm bảo số lượng vi khuẩn như công bố.

Tuy trên thế giới đã có rất nhiều công trình nghiên cứu để định tính và định lượng L. acidophilus trong các chế phẩm đa thành phần, Việt Nam lại chưa có phương pháp tiêu chuẩn định lượng L. acidophilus trong mẫu với nền chứa nhiều chủng vi khuẩn có lợi. Việc xây dựng một phương pháp có độ chính xác cao, thời gian tiến hành ngắn, có thể phân tích trên các nền mẫu chứa nhiều loại vi khuẩn có lợi khác nhau là rất cần thiết. 
Gen Hsp quy định cấu trúc của protein chống chịu sốc nhiệt cho L. acidophilus, chứa một trình tự duy nhất trong hệ gen, đã được công bố trên ngân hàng gen quốc tế và mức độ đa dạng cho phép chúng đặc trưng ở cấp độ loài. Đây là những yếu tố để trình tự gen Hsp phù hợp cho phản ứng realtime định lượng.

Do đó, chúng tôi đã xây dựng phương pháp định lượng nhanh $L$. acidophilus trong men vi sinh bằng kỹ thuật real-time PCR dựa trên trình tự đoạn gen Hsp.

2. VẠT LIẾU VÀ PHƯƠNG PHÁP NGHIÊN CƯU

\subsection{Vật liệu}

- Chủng chuẩn: Bao gồm Lactobacillus acidophilus ATCC 4356, Streptococcus thermophilus ATCC 8317, E.coli ATCC 25922, Bacillus cereus ATCC 10876, Bacillus subtilis ATCC 6633, Lactobacillus rhamnosus ATCC 7469, Bifidobacterium bifidum ATCC 15700.

- Mẫu: 07 mẫu men vi sinh.

\subsection{Thiết bị và hóa chất}

\subsubsection{Thiết bi}

Tủ nuôi cấy kị khí Bactron EZ300, máy real-time PCR Quant Studio 6 Flex, máy điện di ADN, máy đo nồng độ ADN Nanodrop và các thiết bị phụ trợ khác.

2.2.2. Hóa chất

Hóa chất dùng cho real-time PCR định lượng: Power UpTM SYGRTM Green Master Mix Thermo Fisher Scientific, cặp mồi của gen Hsp mồi xuôi: 5'-CTTTGACTCAGGCAATTGCTCGTGAAGGTATG-3', mồi ngược: 5'-CAACTTCTTTAGATGCTGAAGAAACAGCAGCTACG-3' [4]. Bộ kít tách chiết ADN Gene JET genomic ADN pufirication Thermo Fisher Scientific, code: K0722.

\subsection{Phương pháp nghiên cứu}

\subsection{1. Đồng nhất mẫu}

Chủng chuẩn nuôi cấy và mẫu men vi sinh được xử lý và pha loãng theo thập phân (TCVN 6507:2005 [2]).

\subsubsection{Tách chiết $A D N$}

ADN được tách chiết theo kít Gene JET theo hướng dẫn nhà sản xuất. Mỗi $1 \mathrm{ml}$ của các nồng độ chủng chuẩn và mẫu men vi sinh được ly giải bằng lysozyme và proteinase $\mathrm{K}, \mathrm{ADN}$ tiếp tục được hấp thụ trên cột tinh sạch sau đó được hòa lại trong đệm $\mathrm{EB}$, nồng độ $\mathrm{ADN}$ thu được nằm trong khoảng 4 đến $16 \mathrm{ng} / \mu 1$.

\subsubsection{Real-time $P C R$}

Trong nghiên cứu này, chúng tôi sử dụng cặp mồi được thiết kế trong báo cáo của S.R. Herbel [4] để định lượng $L$. acidophilus. Mồi xuôi: 5'-CTTTGACTCAGGCAATTGCTCGTGAAGGTATG-3', mồi ngược: 5'-CAACTTCTTTAGATGCTGAAGAAACAGCAGCTACG-3'[4]. Tiến hành thẩm định cặp mồi này trên nền mẫu men vi sinh và chủng chuẩn [3],[4],[5].

Thành phần một phản ứng: real-time PCR $25 \mu 1$ như sau: Master mix 2x: 12,5 $\mu 1$; Mồi xuôi: $1 \mu 1$; Mồi ngược: $1 \mu 1$; Khuôn ADN: $1 \mu 1 ; \mathrm{H}_{2} \mathrm{O}: 9,5 \mu 1$.

Chu kỳ nhiệt: $94^{\circ} \mathrm{C}, 3$ Phút; 30 lần $\left(94^{\circ} \mathrm{C}, 30 \mathrm{~s} ; 64^{\circ} \mathrm{C}, 30 \mathrm{~s} ; 72^{\circ} \mathrm{C}, 30 \mathrm{~s}\right) ; 72^{\circ} \mathrm{C}, 10$ phút.

2.3.4. Nuôi cấy để xác định nồng độ cho đường chuẩn real-time PCR

Để xác định số lượng vi khuẩn cho đường chuẩn phản ứng real-time $\mathrm{PCR}$, tiến hành song song real-time PCR và nuôi cấy theo TCVN 7849 : 2008 [1]. Mẫu thử được đồng nhất trong dung dịch đệm, pha loãng thập phân, đường chuẩn real-time và nuôi cấy được tiến hành song song trên cùng 1 dãy pha loãng đó.

\subsubsection{Thẩm định phưong pháp}

Thông số thẩm định bao gồm: giới hạn định lượng, độ đặc hiệu và độ lặp lại theo ISO 16140 và AOAC 2016 phụ lục $\mathrm{F}$ về thẩm định phương pháp vi sinh và hóa học.

Giới hạn định lượng: Giới hạn định lượng của phương pháp được xác định dựa trên liên hệ giữa giá trị $\mathrm{Ct}$ của phản ứng real-time $\mathrm{PCR}$ và nồng độ $\mathrm{CFU} / \mathrm{mL}$ phương pháp nuôi cấy tính trên cùng 
dãy nồng độ pha loãng. Từ đó suy ra giới hạn định lượng CFU/mL của phương pháp real-time PCR.

Xác định độ đặc hiệu: Độ đặc hiệu của phương pháp được xác nhận trên kết quả phân tích chủng đích L. acidophilus so với kết quả phân tích mẫu có chứa các chủng cùng chi Lactobacillus như Lactobacillus rhamnosus, và các chủng probiotic thuộc chi khác như Bifidobacterium bifidum, Streptococcus thermophilus, Bacillus subtilis và các chủng vi sinh vật không mong muốn, có thể gây hại cho sức khỏe như Escherichia coli và Bacillus cereus. Cách thức thiết lập được thể hiện trong Bảng 1.

Bảng 1. Thiết lập thông số tính độ đặc hiệu

\begin{tabular}{|c|c|c|c|c|}
\hline \multicolumn{2}{|c|}{ Phép thủ } & \multicolumn{2}{|c|}{ Chủng thử nghiệm } & \multirow{2}{*}{ Tổng } \\
\hline & & Dương tính & Âm tính & \\
\hline \multirow{2}{*}{$\begin{array}{c}\text { Kết quả real-time } \\
\text { PCR }\end{array}$} & Dương tính & $\mathrm{a}$ & $\mathrm{c}$ & $\mathrm{a}+\mathrm{c}$ \\
\hline & Âm tính & $\mathrm{b}$ & d & $b+d$ \\
\hline \multicolumn{2}{|c|}{ Tổng } & $a+b$ & $\mathrm{c}+\mathrm{d}$ & 6 \\
\hline
\end{tabular}

Công thức tính độ đặc hiệu:

Độ đặc hiệu: = số trường hợp âm tính thật/(số trường hợp âm tính thật + số trường hợp dương tính giả $)=\mathrm{d} /(\mathrm{d}+\mathrm{b}) * 100$.

Trong đó: $a$ : số kết quả duơng tính giả; b: số kết quả âm tính giả, c: số kết quả duơng tính, d: số kết quả âm tính.

Xác định độ lặp lại: Độ lặp lại xác định theo ISO 16140, lặp lại 7 lần giá trị độ lệch chuẩn Sr yêu cầu phải nhỏ hơn 0,125 . Độ lệch chuẩn được tính theo công thức: $\mathrm{S}_{\mathrm{r}}$

$$
\mathrm{S}_{\mathrm{r}}=\sqrt{\frac{\sum\left(x_{i}-\bar{x}\right)^{2}}{n-1}}
$$

Trong đó: $\quad x_{i}$ : Kết quả của môi lần lặp lại,

x: kết quả trung bình của các lần lạ̣p lại; $n$ : số lần lạ̣p lại $(n=7)$

\section{KẾT QUẢ VÀ BÀN LUẬN}

\subsection{Kết quả}

\subsubsection{Tách chiết $A D N$}

Chủng chuẩn và mẫu vi sinh được tách chiết bằng bộ kít tách chiết $\mathrm{ADN}$ Gene JET, sản phẩm $\mathrm{ADN}$ được kiểm tra nồng độ trên máy Nanodrop, hàm lượng từ 4 đến $16 \mathrm{ng} / \mu 1$, độ tinh sạch nằm trong khoảng 1,8 đến $2,1 \mathrm{ng} / \mu 1$, hàm lượng và độ tinh sạch đảm bảo làm khuôn mẫu của phản ứng real-time PCR.

\subsubsection{Xây dựng đường chuẩn và định lượng}

Đường chuẩn được tiến hành trên các mẫu thử được pha loãng thập phân từ nồng độ $10^{4}$ đến $10^{9}$ $\mathrm{CFU} / \mathrm{mL}$ kết quả được thể hiện trên hình 1 .

Trong hình 1a các nồng độ pha loãng kép có đường cong khuếch đại tuyến tính với nhau, trong hình $1 \mathrm{c}$ phân tích đỉnh nóng chảy cho thấy các sản phẩm đều nằm trên $81^{\circ} \mathrm{C}$ chứng tỏ tính đặc hiệu cao của sản phẩm khuếch đại, hình $1 \mathrm{~b}$ và $1 \mathrm{c}$ đường chuẩn có giá trị $\mathrm{r}=9,95$ phù hợp để tính kết quả định lượng, mẫu thử nằm trong khoảng nồng độ $10^{6}-10^{8} \mathrm{CFU} / \mathrm{ml}$.

\subsubsection{Giới hạ định luợng}

Giới hạn định lượng của phương pháp được xác định dựa trên sự liên hệ tuyến tính giữa nồng 


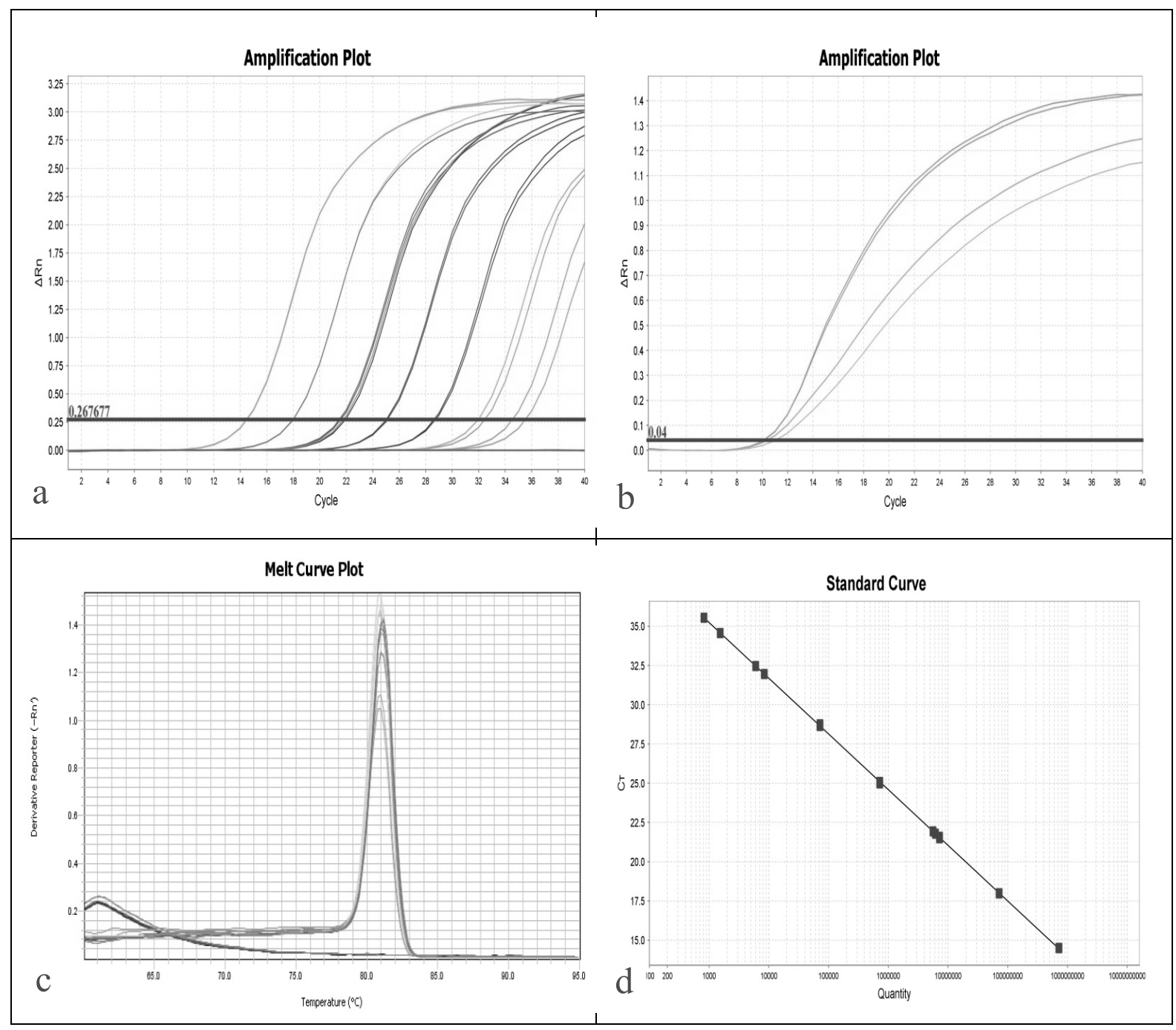

Hình 1. Kết quả định lượng L. acidophilus trong mẫu men vi sinh.

(a) Đưòng cong khuếch đại của chuẩn, (b) Đường cong khuếch đại chuẩn và mẫu,

(c) Phân tích độ đặc hiệu của sản phẩm khuếch đại bằng đỉnh nóng chảy,

(d) Phương trình đường chuẩn.

\section{Amplification Plot}

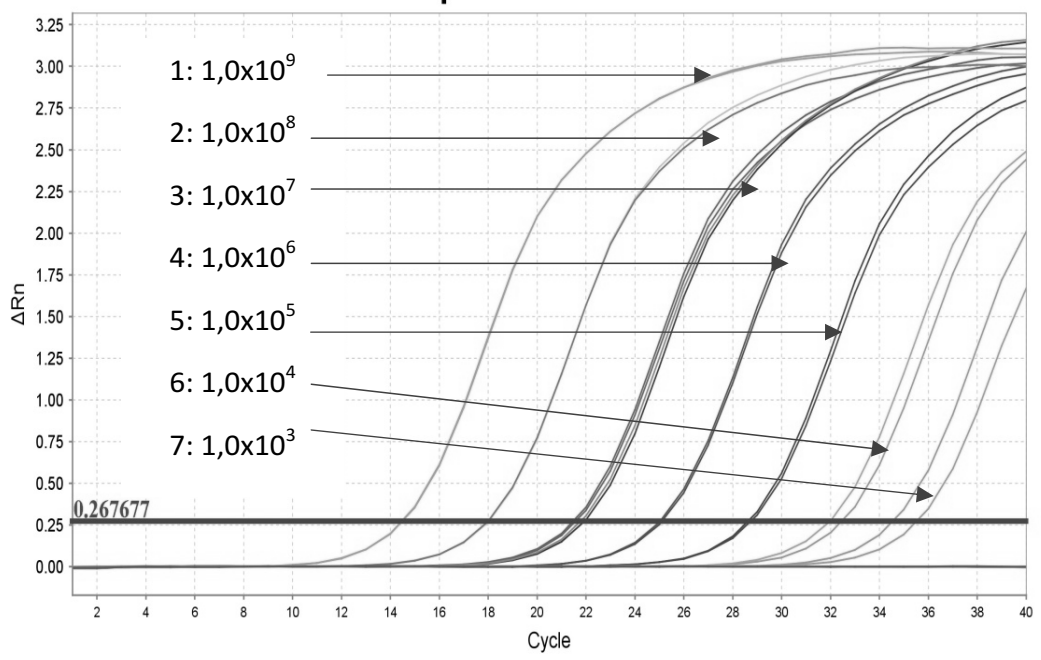

Hình 2a. Xác định giới hạn định lwợng 


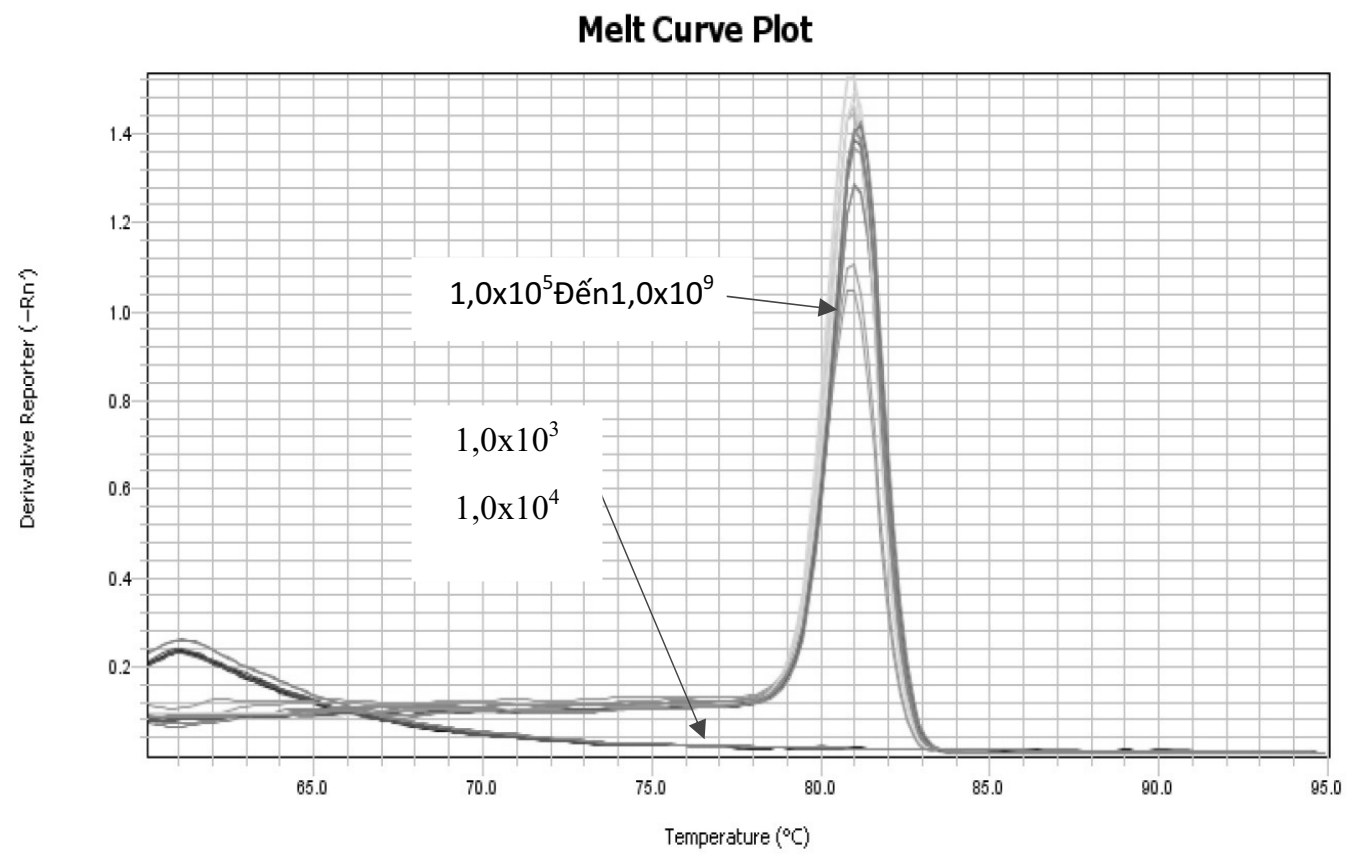

Hình 2b. Phân tích đỉnh nóng chảy của sản phẩm khuếch đại

độ của phương pháp nuôi cấy và giá trị $\mathrm{Ct}$ khi hai phương pháp tiến hành trên cùng một dãy nồng độ pha loãng (Hình 2), giới hạn định lượng là $10^{5} \mathrm{CFU} / \mathrm{mL}$.

Theo hình $2 \mathrm{a}$ ở nồng độ $1,0 \mathrm{x} 10^{5} \mathrm{CFU} / \mathrm{mL}$ là giới hạn định lượng của phương pháp. Để khẳng định lại, tiến hành phân tích giá trị đỉnh nóng chảy của sản phẩm khuếch đại, trên hình $2 \mathrm{~b}$ cho thấy nồng độ từ $1,0 \times 10^{5}$ đến $1,0 \times 10^{\circ}$ giá trị đỉnh nóng chảy ở là $81^{\circ} \mathrm{C}$, còn ở nồng độ $1,0 \times 10^{4}$ và $1,0 \times 10^{3}$ đỉnh nóng chảy dưới $61^{\circ} \mathrm{C}$, đây là sản phẩm khuếch đại không đặc hiệu.

\subsection{4. Đô đăc hiệu}

Độ đặc hiệu xác định theo mục 2.3.5 tiến hành phản ứng real-time L. acidophilus cùng với các chủng không đặc hiệu trên hình 3 là phản ứng tiến hành với Lactobacillus rhamnosus cho thấy kết quả dương tính với $L$. acidophilus và âm tính với Lactobacillus rhamnosus.

\section{Amplification Plot}

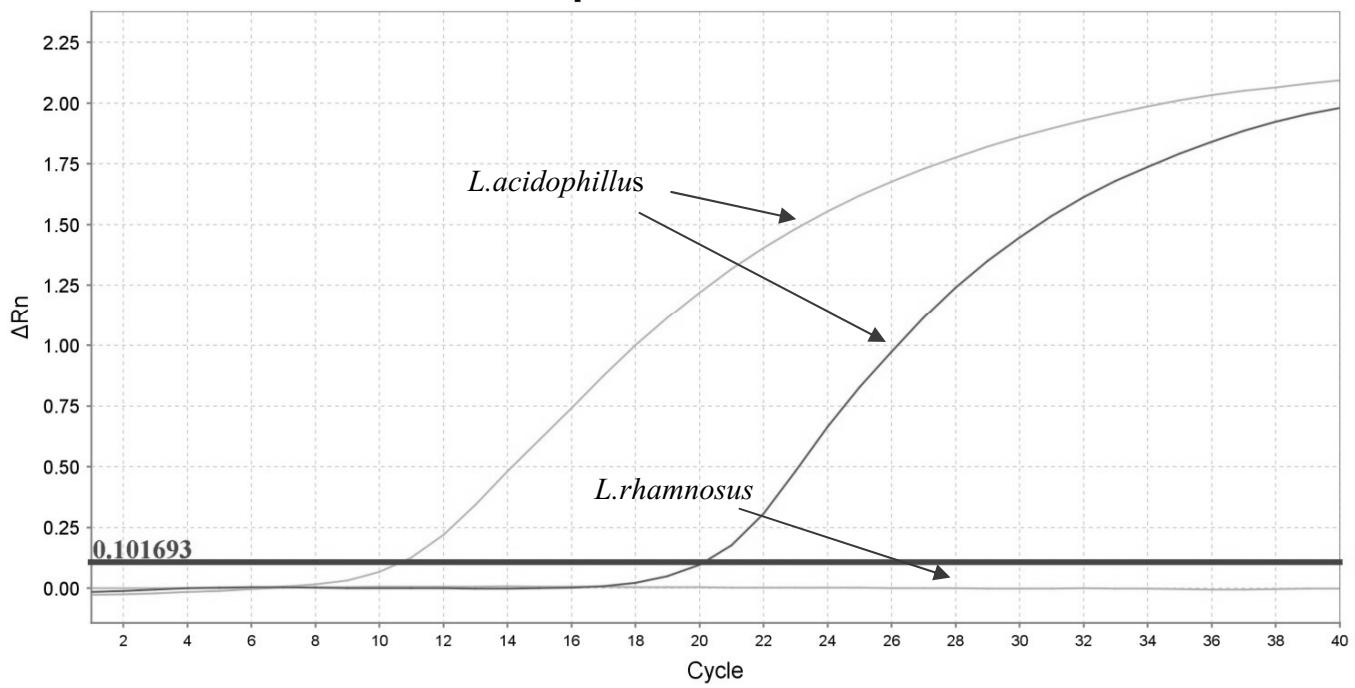

Hinh 3. Kiểm tra độ đặc hiệu của phản úng real-time

Tiến hành với tất cả các chủng còn lại thu được kết quả trong Bảng 2. 
Bảng 2. Độ đặc hiệu của phương pháp

\begin{tabular}{|l|l|c|c|}
\hline STT & \multicolumn{1}{|c|}{ Tên chủng } & $\begin{array}{c}\text { Nguồn gốc, } \\
\text { mã số chủng }\end{array}$ & $\begin{array}{c}\text { Kết quả real-time } \\
\text { PCR }\end{array}$ \\
\hline 1 & Lactobacillus rhamnosus & ATCC 7469 & Âm tính \\
\hline 2 & Streptococcus thermophilus & ATCC 8317 & Âm tính \\
\hline 3 & E.coli & ATCC 25922 & Âm tính \\
\hline 4 & Bacillus cereus & ATCC 10876 & Âm tính \\
\hline 5 & Bacillus subtilis & ATCC 6633 & Âm tính \\
\hline 6 & Bifidobacterium bifidum & ATCC 15700 & Âm tính \\
\hline 7 & Lactobacillus acidophilus & ATCC 4356 & Dương tính \\
\hline
\end{tabular}

Áp dụng công thức xác định độ đặc hiệu trong mục 2.3 .5 và số liệu bảng 2 ta có: $\mathrm{d} /(\mathrm{d}+\mathrm{b}) * 100=6 / 6=100 \%$, độ đặc hiệu của phương pháp là $100 \%$.

\subsection{5. Độ lặp lại}

Độ lặp lại của phương pháp được tiến hành lặp lại 7 lần trên nền mẫu men vi sinh. Kết quả được thể hiện trong Bảng 3.

Áp dụng công thức tính độ lặp lại trong mục 2.3 .5 và tiêu chuẩn ISO 16140 cho thấy trên nền mẫu đều có độ lặp lại phù hợp $\mathrm{S}_{\mathrm{r}}<0,125, \mathrm{RSD}=5,0$, đạt yêu cầu về độ lặp lại.

Bảng 3. Độ lặp lại trên nền men vi sinh

\begin{tabular}{|c|c|c|c|c|}
\hline STT mẫu & Khối lự̛ng cân (g) & $\begin{array}{c}\text { Hàm lự̆ng } \\
\text { (CFU/g) }\end{array}$ & $S_{r}$ & $\begin{array}{r}R S D \\
(\%)\end{array}$ \\
\hline 1 & 10,04 & $2,4 \times 10^{6}$ & \multirow{7}{*}{0,006} & \multirow{7}{*}{5,0} \\
\hline 2 & 10,06 & $2,1 \times 10^{6}$ & & \\
\hline 3 & 10,07 & $2,7 \times 10^{6}$ & & \\
\hline 4 & 10,02 & $2,4 \times 10^{6}$ & & \\
\hline 5 & 10,10 & $2,0 \times 10^{6}$ & & \\
\hline 6 & 10,02 & $2,5 \times 10^{6}$ & & \\
\hline 7 & 10,01 & $2,2 \times 10^{6}$ & & \\
\hline
\end{tabular}

\subsubsection{Bàn luân}

Giới hạn định lượng của phương pháp là $10^{5} \mathrm{CFU} / \mathrm{mL}$ đối với các sản phẩm đa lượng bổ sung L. acidophilus, yêu cầu về chất lượng thường phải lớn hơn $10^{6} \mathrm{CFU} / \mathrm{g} / \mathrm{mL}$, độ đặc hiệu là $100 \%$, tiêu chuẩn ISO 16140 cho thấy trên nền mẫu đều có độ lặp lại phù hợp $\mathrm{S}_{\mathrm{r}}<0,125, \mathrm{RSD}=5,0$, đạt yêu cầu về độ lặp lại. Do đó phương pháp hoàn toàn phù hợp. Theo nghiên cứu của S.R.Herbel và cộng sự [4] trên nền mẫu men vi sinh với các chủng Lactobacillus, giới hạn định lượng của phương pháp real-time PCR định lượng từ $10^{5}$ đến $10^{6} \mathrm{CFU} / \mathrm{mL}$.

Về giá thành phương pháp real-time PCR chỉ bằng một nửa so với phương pháp nuôi cấy kỵ khí và thử nghiệm hóa sinh, hơn nữa với thời gian phân tích chỉ từ 4 giờ đến 6 giờ so với thời gian của phương pháp nuôi cấy ít nhất từ 3 đến 5 ngày, phương pháp có thể đáp ứng nhu cầu cần phân tích nhanh của xã hội.

\section{KẾT LUẬN}

Đã xây dựng được phương pháp real-time PCR định lượng cho L. acidophilus trong nền mẫu 
men vi sinh. Với độ đặc hiệu $100 \%$, độ lặp lại $\mathrm{S}_{\mathrm{r}}<0,125$ và giới hạn định lượng của phương pháp ở $10^{5} \mathrm{CFU} / \mathrm{g} / \mathrm{mL}$.

\section{TÀI LIẸU THAM KHẢO}

1. TCVN 7849 : 2008. "Sữa và sản phẩm sữa - Định lượng Lactobacillus acidophilus giả định trên môi trường chọn lọc - kỹ thuật đếm khuẩn lạc ở $37^{\circ} \mathrm{C}$ "

2. TCVN 6507:2005 (ISO 6887: 1999). "Vi sinh vật trong thực phẩm và thức ăn chăn nuôi - Chuẩn bị mẫu thử, huyền phù ban đầu và các dung dịch pha loãng thập phân để kiểm tra vi sinh vật"

3. Danfeng Song, Salam Ibrahim and Saeed Hayek, 2015, "Recent Application of Probiotics in Food and Agriculture Science". Immunology and Microbiology, edited by Everlon Cid Rigobelo. ISBN 978-953-51-0776-7

4. S.R. Herbel, et al., 2013, "Species-specific quantification of probiotic lactobacilli inyoghurt by quantitative real-time PCR, Journal of Applied Microbiology. ISSN 1364-5072

5. Mikael Kubista, et al., 2006, "The real-time polymerase chain reaction", Molecular Aspects of Medicine, 27 p. $95-12$

Summary

\section{QUICK LACTOBACILLUS ACIDOPHILUS QUANTIFICATION IN PROBIOTICS USING REAL-TIME PCR}

\section{Pham Thi Le Quyen, Pham Nhu Trong, Nguyen Thuy Linh, Nguyen Thanh Trung}

National Institute for Food Control

Lactobacillus has a biological effect to supports digestion system. Therefore, it is widely used in dairy products such as yoghurt, food additives and pharmaceuticals. Lactobacillus acidophilus (L. acidophilus) is often used in fermented dairy products such as yoghurt and functional products. However, in Vietnam, there is currently no standard method for quantifying L. acidophilus. In this study, a quantitative method of L. acidophilus using real-time PCR based on a specific fragment of Hsp gene was developed. The limit of quantification of the method is $10^{5} \mathrm{CFU} / \mathrm{g} / \mathrm{mL}$ that is suitable for quality assessment of probiotic products with greater quality claims than $10^{6} \mathrm{CFU} / \mathrm{g} / \mathrm{mL}$. The specificity of the method is of $100 \%$ when compared with nonspecific strains and repeatability is of $\mathrm{S}_{\mathrm{r}}<0.125$ in accordance with the requirements of ISO 16140: 2005 and AOAC: 2016 annex F for method evaluation microbiology.

Keywords: Lactobacillus acidophilus, Real-time PCR, probiotics. 